\title{
"The body says: I am a party": The (im)possibility of regulating the body by law
}

\author{
OÑATI SOCIO-LEGAL SERIES VOLUME 11, ISSUE 3 (2021), 696-721: INVESTIGATIONS - \\ INVESTIGACIONES - IKERLANAK \\ DOI LINK: HTTPS://DOI.ORG/10.35295/OSLS.IISL/0000-0000-0000-1173 \\ RECEIVED 29 FEBRUARY 2020, ACCEPTED 08 SEPTEMBER 2020
}

\section{PÂMELA COPETTI GHISLENI* (D) DOGLAS CESAR LUCAS* (D)}

\section{Abstract}

The rationalism of the seventeenth century inaugurated a new way of thinking to establish that access to the world occurred through rationality. The individualist conception of society that emerged from the eighteenth century, despite having placed the subject in the center, made it from its psychic dimension, relegating the biological body to the second place. In the twentieth century however, Freud recalls the theme of the body to enter again the individual in his materialistic body. Therefore, it was restored and deepened the theme of meat, carcass, organic and biological body. Thus, the present study aims, from the hypothetical-deductive method, to analyze the (im)possibility of body regulation, especially the female one, by the contemporary law, and its practical implications for women to, in the end, conclude that the body and their narratives are at the root of inequality and gender oppression.

\footnotetext{
* College CNEC Santo Ângelo/RS, Brazil. Graduated in Law from the Regional University of the Northwest of Rio Grande do Sul - UNIJUÍ and master's degree in Law, with emphasis on Human Rights, from the Stricto Sensu Postgraduate Program in Law at UNIJUÍ. Professor of the Law Graduation Course at CNEC Santo Ângelo College (Rio Grande do Sul - Brazil), member of the Human Rights Commission of the $23^{\text {rd }}$ Subsection of OAB/RS and Lawyer (OAB/RS 100.497). Email address: 1432.pamelaghisleni@cnec.br

* UNIJUÍ/RS and College CNEC Santo Ângelo/RS, Brazil. Graduated in Law from the Regional University of the Northwest of Rio Grande do Sul - UNIJUÍ (1998), Master in Law from the Federal University of Santa Catarina (2001), Doctorate in Law from UNISINOS (2008) and Post-Doctorate in Law from the University of Studies by Roma Tre (2012). Professor of Undergraduate, Master and Doctorate in Law at the Regional University of the Northwest of the State of Rio Grande do Sul - UNIJUÍ and professor in the Law Course at College CNEC Santo Ângelo. Collaborating Professor in the Master and Doctorate in Law at University URI - Santo Ângelo/RS. Chief Editor of the Human Rights and Democracy Journal (B1). Coordinator of the Human Rights and Democracy Collection, published by UNIJUÍ publisher. Evaluator of MEC/INEP. Researcher at Instituto Jurídico Portucalense, in the research group Dimensions of Human Rights. Collaborating researcher at IBEROJUR, in the thematic area of Philosophy of Law and Fundamental Rights. Leader of the CNPq Research Group "Critical foundation of human rights". Email address: doglasl@unijui.edu.br
} 


\section{Key words}

Body; law; woman; regulation; sexuality

\section{Resumen}

El racionalismo del siglo XVII inauguró un nuevo pensamiento que establecía que el acceso al mundo ocurría a través de la racionalidad. La concepción individualista de la sociedad que emergió del siglo XVIII, pese a haber colocado al sujeto en el centro, lo había hecho desde su dimensión psíquica, relegando el cuerpo biológico a un segundo plano. En el siglo $X X$, en cambio, Freud recupera el tema del cuerpo y resitúa al individuo en su cuerpo material. Por tanto, los temas de la carne, carcasa, y cuerpo orgánico y biológico se restauran y se profundiza en ellos. Así pues, este artículo pretende analizar, a través del método hipotético-deductivo, la (im)posibilidad de regular el cuerpo, especialmente el femenino, por el derecho contemporáneo, y las implicaciones prácticas para las mujeres. Finalmente, concluimos que el cuerpo y sus narrativas están en la raíz de la desigualdad y de la opresión de género.

\section{Palabras clave}

Cuerpo; derecho; mujer; regulación; sexualidad 


\section{Table of contents}

1. Introductory considerations 699

2. The body between biology and biography, between nature and culture:

itineraries of an ambivalence 700

3. Who and what constructed (visibilized) female bodies throughout history? ............ 704

4. Moi-peau: Decifying the female body (and the female world) 707

5. "Your body is a battleground": The law approves the female body ..........................713

6. Final considerations

References 718

Legal sources 721 
La Iglesia dice: El cuerpo es una culpa. La ciencia dice: El cuerpo es una máquina. La publicidad dice: El cuerpo es un negocio. El cuerpo dice: Yo soy una fiesta.

(Eduardo Galeano)

\section{Introductory considerations}

In The skin I live in, the always deep Pedro Almodóvar makes us think about who is the self that inhabits the skin, who is the being that lives in the body. The experience in this film is extremely rich in that it tells the story of Robert, a doctor whose experiences did not allow him to mourn the absence (perhaps more physical) of his beloved wife. Norma, daughter of the scientist, is a young woman tormented by having witnessed her mother's death and, in a truly threshold act, is raped by Vicente. From there, the feeling of revenge comforts Robert, who starts to impose a forced transsexualization on the boy, who is baptized as Vera. The spectator then wonders whether the guinea pig has assumed the characteristics of the new body (and the new sex) or not. It is perceived that he does it, but only as a way to survive in the confinement created by Robert. In the end, therefore, it turns out that Vera was always just the wrapper that encapsulated Vicente.

Who would recognize us if we were framed in another sex, in another skin, in another body, in another face, in another laugh, even if we kept our essence in its entirety (if that is possible)? It is that the skin is perhaps, in fact, the most profound, to remember a maxim of Paul Valéry and, at the same time, the most wide-open. The body is the active or passive interpreter of what we are, in the sense that it allows objectification of the subjectivity of being. It makes it possible (or not) to see what is most profound. It is in the psyche, but also in the body and skin, that the particular events in the history of each individual are inscribed. This is intended to demonstrate that there is no gulf between body and being, carcass and mind. In reality, what separates each "opposite" of this binary pair is a fine line that allows you to hide or strip, undermine or reveal.

In view of all these turbulences that involve the psychic body and the somatic body, this article seeks to work with the idea that only the biological body allows the subject to cling to his own existence. We chose to use special emphasis on the issue of women, as, for a long time in history and even today, the female body is a controversial stage in which ideologies, discourses and narratives are inscribed that determine stereotyped expectations of sexual roles. It is that in this binary game of the male and the female, history, philosophy, medicine, pedagogy, psychology and, ultimately, the law, took charge (and still take charge) of making the woman small, inferior, frivolous.

To carry out the research, works related to the theme available in physical media and on the world wide web were studied. To this end, the contributions of a wide range of disciplines, such as anthropology, psychology, psychoanalysis, medicine, history and law, were fundamental. The first point is intended to make some contributions related to approximations between body and being, in an attempt to justify and demonstrate that the psychic and biographical body does not depart from the somatic and biological. In the second and third items, we move on to the approach of female specificities with regard to the body and the power relations that surround (and in it) orbit. Finally, the last point of the research assumes that, as the $20^{\text {th }}$ century puts the issue of the materially 
considered body on the agenda, the legal system also regulates (and castrates) the freedoms that bodily experience it offers subjects, especially women.

Francis Bacon said he was surprised by the fact that in a butcher shop he always found an animal, not a man. In fact, we are a potential carcass. And being that, we are already a lot. However, paradoxically and in an almost schizophrenic way, we cannot be just meat, under penalty of reducing Vicente to Vera, because a body is never just a body. It is an infinite number of possibilities and must be deciphered in the course of our existence.

\section{The body between biology and biography, between nature and culture: itineraries of an ambivalence}

Nature and culture are two terms used to designate the ambivalence with which the body was expressed in primitive societies and the equivalence to which it was reduced in contemporary society by the set of codes that govern it and by the most varied types of inscriptions that reach it. In primitive societies, the body was not an anatomical entity that could be perceived in isolation and that we identified as the uniqueness of each individual. In this logic, the body was community, social, an area in which the group's senses and signs were expressed. Nature and culture were not separated at this time and the body was the stage for the representations of the community. Therefore, the body did not have an identity here, but a place. In contrast, in post-traditional societies, the body acquires a value, it is given its own meaning. The body is cultivated and, gradually, its biology is separated from its biography. In this itinerary, mind and body are also separated.

The body has already been interpreted through the lens of different knowledge and structures, as an organism to be healed, as a work force, as "flesh" in search of forgiveness, as an unconscious to be released, as a support for a set of signals to be transmitted. As a floating meaning, the body, highlights Galimberti (2010), confuses the codes coming from different narrative structures, with a symbolic operation that consists of composing that disjunction in which each code articulates when it divides the true from the false, the good from the evil etc., obtaining a kind of bivalence in which the positive and the negative are reflected, producing that imaginary reality that is at the origin of all speculation on the subject.

Proposing itself as this, but also as that, the body, which is granted to all inscriptions and also to reductions, with its ambivalence causes all sorts of oscillations and stratifications. From the center of symbolic irradiation in primitive communities, the body was transformed in the West into the negative of each value, which knowledge, with the complicity of power, tried to expand. From the body, described by Plato in Fédon (1996), taken from fears, passions and pleasures, from which the soul must maintain isolation in order to be pure, to the body full of deviations and maleficence denounced in the biblical discourse, from the Cartesian laceration of its unity to its anatomy operated by science, the body seems to see part of its history completed with its reduction to the labor force in the economy, in which the idea of accumulating value is more evident, but which also challenges the body from the perspective of its ambivalence .

The challenge to which the body is submitted does not mean that it opposes anything or anyone, but simply that it does not allow itself to be taken by a fullness of meaning and 
value, not because it has objections or restrictions, but because the fullness of the senses and of values it grows on its mortification. At the same time that the name is removed, its identity makes it possible to elaborate new and against meanings. By dissolving his name, he resolves his identity in relation to his surroundings.

The finding of the reduction of the symbolic ambivalence of the body to a general equivalent of value is not a harbinger of the liberation of the body, of the restitution of its expression against the repression of some type of system. Strangely and paradoxically, this discovery of the body, which is presented as a premise for its release, is used, says Galimberti (2010, p. 13):

To liquidate it definitively in the gear of the system and its production which, not content with exploiting its workforce, also exploits the power of Desire, hallucinating it with those ideals of beauty, youth, health, sexuality which are the new values. for sale.

The body occupies a place in the world and contracts habits in a space that does not ignore it. But at the same time, the body, to maintain itself as such, cannot be colonized by the world, because its presence is guaranteed in the possibility of maintaining itself as a project, as outside itself, as an intention, as a future projection, continues Galimberti. The Cartesian narratives that separated body and mind reduced the body to a mere object of nature and are unaware that the body is a space and has its own status populated by countless forms of representation, which has different ways of acting and revealing itself. The body is itself a space in the world and as far as its presence extends, the body itself extends, because that is its space (Galimberti 2010).

Each human act reveals that the presence is corporeal, the body being my form of appearance. The figure is not just an image of me, but it is myself. It is not the appearance of a transcendental self, but the perfect identity between being and appearing, and accepting that identity is a fundamental condition for balance. Just as there is no thought outside the word that expresses it, "all that way there is no one like your body, but your body is like that in your life" (Galimberti 2010, p. 16). The body is a place of inscription and its form of presentation, each sign it carries makes the body a memory. The body is crossed by existence, it is existence itself in the form of presence and appearance. Embodying a symbol, the body consigns a group identity which must be assimilated by the removal of differences. In this sense, and this has its cruel aspect, the body does not say about itself, but about the signifiers that marked it. As an inscription stage, it is limited to being the name of a concept. Paradoxically, in order to dominate the body, very differently from the traditional societies that inscribed social meanings in the body, contemporary society does not impose meanings, but that empties all the signs that the body could consign. In this respect, the role of tattoos and body marks in traditional societies is striking (indigenous people are a good example among us), which showed a social sign present in the subject and were not prisoners of specific codes as they are today.

In assuming itself as a place for various senses, the body is emptied of meanings and transcends its own nature. Marked from different codes (discipline, beauty, desire, needs etc.), the body is produced dangerously in a transgression, since adherence to different codes imposes the negation of each one of them in particular, considering that the ambivalent game is it constitutes based on a relationship established with its opposite, not considering the versatility with a possibility present in the difference. The many 
marks that the body can assume brought the cost of flexible identities, the reduction of community narratives and the stratification of the senses about the same sign. And it is precisely in this inability to narrate the body a priori, as a place of closed social inscription, that its capacity to reinvent itself all the time and more and more is found, as a possibility and as to become the subject. Since it is not just one thing, many signs can appear, several can be abandoned and many positive reframes tend to take shape once and for all. The case of the new potentialities of sexuality revealed in and by the body fall into this scenario.

A sophisticated way of perceiving identity as a social construction is its relationship with the body and in the body. The body carries the biological characteristics of the subject. The identity, in turn, is the social construction of his biography. According to Eligio Resta $(1997,2011)$, identity and body are categories that come closer, get closer, that diverge, but that are not confused and that each claim their particular autonomy. As a biological unit, the body is a natural event that has its own plot and that gets out of control. Color, gender, sexuality and many other biological attributes are not the subject's choice. As a discursive construction, the body manifests itself as a place of innumerable representations and its identity is presented as one of the possibilities of this representation. In identity, biology and biography are interrelated through the elaboration of meanings and a specific, codified language, which transforms the objectivity of the body, its nature, into a privileged space of authentic, particular manifestations. More than an essentiality, the body acquires its own grammar and semantics, which are the results and processes of a certain form of social construction. A social life is installed in the body, which represents more than a biological life. Life manifests itself in the body, it is the body. It claims and constitutes an identity that guarantees its biography, its speech and its particular way of being in the world.

Although contemporary consumerist society seems to privilege and cultivate the body as an object, as an instrument, as a way of enhancing one's own personal identity, it is definitely much more than that; a project can be read in it and in its transformations. Subject and body do not separate. The body cannot be reduced to a corporeal, static image, which "operates as an object of which we can have a clear image" (Featherstone 2009 , n.p.). He hides and reveals; carries past and becoming. It is objective reality and subjective manifestation. The body is released from its biology, even if in it, and is discovered in its discursive feature, as a construction that inhabits the world, that opens to the world and that can reveal itself in different ways (Galimberti 2010). The body is not a flat surface on which the individual and society write their symbols and representations in a disconnected and random way. The body is born in a world that is always inhabited and opens to it. The body space is diverse. It is not a single space, but a multiple space. In it operate several relations at the same time, several discontinuous and moving spaces. But it also stands out in a specific space, which is only possible through the encoding and decoding processes that go through it. Encoding, recoding, decoding are operations that particularize the many representations that inhabit the subject's body and give him identity and recognition. The body is also a space in which the subject's life problems acquire a particular way of manifesting themselves.

The body definitely speaks and complains. But it does so because of its biography, for the countless "selves" that give it historical, affective, sexual meaning etc. It has its own 
way of manifesting itself. It requires protection standards that fully recognize it. Modern equality protects the body in its condition of abstract and universal equality. Freedom to come and go; freedom to think; freedom of worship, economic freedom. These are freedoms of this kind, freedoms of a universal character, which, to some extent, do not deal with differences as a positive value. For this very reason, gender, color, religiosity, sexuality, true manifestations of the various "selves" imprisoned in the biological body, were practically disregarded, set aside, opposed, in the name of a homogeneous universal equality. In this modern model, national identity practically depletes belonging, and the body and the "I" are related in a less complex way. The body, its biology, seems to colonize the " $\mathrm{I}$ ", its biography, silencing it, denying its visibility as a positive value.

If in the past the identity allowed only an almost static identification, an unchangeable identity, the identity has freed itself and disposes of itself naturally and with strength to make constant changes in its own grammar of identifications. And therein lies a problem: the biography with which we write our identity is transformed, it ceases to be stable and becomes temporary and multiple. In identity formation, the biology of the body and its biography are dynamically interrelated. The body expresses itself in new languages, visits new environments, lives with new differences. This rich experience of encounters that the man's body undergoes and is subjected to in contemporary society, prompted, necessarily and as a way to identify its particularities, the appearance of new biographies coexisting together and reproducing multiple identities present in one body.

The body, notably in the contemporary world, more than at any time, lives in several spaces at the same time. Work, tourism, sexuality, education, religiosity etc., are spaces inhabited, at the same time, by the body. Some of these places already refer to an identity with its own status and a map that allows good circulation. Other spaces, in turn, are new and challenging. Staying identified in just one place, in this scenario of multiplicity, is difficult. For this reason, identity tends to produce new mediations, rearranging space, its narrative, its history. He manages to continue his connections because he is able to reorganize different units and make new combinations in this sea of multiple spaces. Such a task is important and necessary to guarantee stability, even if temporary (Resta 2011).

Thus, several "selves" sprout from the same body. It is no longer a proletarian body, only, although it may also be, that is exhausted in demands for redistribution and that does not know the world beyond the factory. Nor is the body reduced to a concept of national citizen. The body is completely unveiled. He speaks of himself; he becomes a multiple actor who reveals himself through the discourse of his various "selves" at the same time. A body, therefore, reveals several biographies that produce its own memory, its own status of identification that reproduces its particularity in the world.

It is also necessary to consider that the body is a repository of biological manifestations that function as a code of communication and identification of certain qualities and shared characteristics, and with that the biology of each subject tends to constitute a biographical instance of retelling and reproducing the history of the own body. In this case, identity as memory leads to a kind of meaning that needs to recognize and value objective attributes of the body itself and its biological representation as elements of differentiation and equality. Color, race, sexuality, age, etc., although they can be read 
in their symbolic dimensions, they profile a type of body recognition that individually identifies each one of us in particular and associates us with a set of similar ones by sharing biological attributes, for the narrative of a biography he identifies.

As a manifestation of a biography, identity is a trait of being, a mechanism for revealing its particularity. Biography as a social construction is much richer and more complex than its correspondence in legal terms. While law regulates and reduces complexities through congruent generalization, identity feeds on ambivalences and paradoxes that cannot be typified by the lawful or illicit sign.

This appropriation of bodies, biographies and identity traits - based on the "licit-illicit" binary - has had particularly relevant consequences with regard to female bodies. This is because, although male bodies are also colonized by oppressive "castrating" structures, which determine what a male body, a male body or a fragile body is, one cannot lose sight of the fact that the controversial, schizophrenic and hysterical is, historically and culturally, the feminine. He is at the dawn of a series of discussions and claims that in contemporary times will deal with the singularities of "other" bodies: transgender, transsexual, androgen, transvestite, drag queen and those countless other ways of being and existing that they are not in the field of lawfulness, they can only be condemned to illegality. In this sense, and starting from this idea developed so far of the body as a biographical stage of being, the next item of the study will analyze the discourses that permeated the female body throughout history.

\section{Who and what constructed (visibilized) female bodies throughout history?}

In addition to a historical construction, the female body has become an object of study of philosophy, medicine, pedagogy, psychology and also law (Colling 2014). With that, a regulation was established regarding the female body that involves all its lines, leaving no margin of interpretation and experience for the subject whose biography is written in female flesh. It is possible to affirm that this made in anthropology and feminist theory in general, the main reference has always been the internal body (the biographical body), relegating itself to the biological body, the meat, the carcass, a secondary place in terms of relevance. It so happens that the history of women and their struggle is not separate from the history of their bodies.

The model of society recognized and accepted until before the $17^{\text {th }}$ and $18^{\text {th }}$ centuries was called organicist or holistic, in which the state was superior and prior to individuals. The new reference that emerges from the $18^{\text {th }}$ century begins to draw a notion of the individual as the center and, therefore, prior and superior to the structure of the State of the whole. In general, this leads to greater protection for the individual singularly considered in his human dimension, that is, for the simple fact of being human (Bedin 1997). This rationalist wave brought with Descartes another way of thinking that established that access to the world was given through rationality. Therefore, the correct, true and legitimate way to understand the world, access it, build it and transform it was through reason. Needless to say, these circumstances caused the organic body to be relegated to the background. In this sense, for Aníbal Quijano (2005, p. 129):

With Descartes what happens is the mutation of the old dualistic approach about 'body' and 'non-body'. What was a permanent co-presence of both elements at each stage of the human being, in Descartes becomes a radical separation between 'reason/subject' 
and 'body'. The reason is not only a secularization of the idea of 'soul' in the theological sense, but a mutation in a new id-entity, the 'reason/subject', the only entity capable of 'rational' knowledge, in relation to which the 'body' is and cannot be anything other than the 'object' of knowledge. From this point of view, the human being is, par excellence, a being endowed with 'reason', and this gift is conceived as located exclusively in the soul. Thus, the 'body', by definition incapable of reasoning, has nothing to do with reason/subject.

The first historical discourse responsible for determining social roles lies in Plato (427$437 \mathrm{BC}$ ). The philosopher approaches childbirth and thought on the grounds that thinking is giving birth. However, when he compares the crafts of the philosopher and the midwife, he warns that theirs is inferior to his. In general, he points out that women are weak and men are strong, when he questions Glaucus as follows:

Are you aware of any human activity in which men do not outperform women? Will we extend our speech by mentioning weaving, confectionery and cooking, jobs that seem appropriate to women and where the inferiority of men is highly ridiculous? (Plato 1997, p. 154).

Likewise, the Greek philosopher Aristotle (384-322 BC) praised the male rationality at the expense of the female. For him, "among animals, it is the human being who has the most developed brain, in proportion to its size; as well as the brain is bigger in men than in women" (Aristotle 2010, p. 79).

Hippocrates (460-377 BC), Father of Medicine, incorporated Plato and Aristotle in his speech by stating that the uterus circulated inside the woman's body. He believed that women who had relationships with men were in better health. Biologically, therefore, it corroborated the female fragility when mentioning that the woman's body is more humid, insofar as it resembles a woollen fabric, whereas the man's body, for having a smaller, tighter and denser weave, retains less liquid (Hippocrates 2007).

Another argument in this sense, of female incompleteness in medical terms, was carried out by Galen (130 AD), a Greek doctor, who stated that the lack of heat prevented the women's genitals from descending, being hidden. Male anatomy, therefore, was seen as exterior and perfect (Bozon 2004). According to Foucault (2014a, p. 135), Galen “... supposes the emission of sperm from women as in men, the difference being that the elaboration of this mood is less perfect and less complete in women: what explains its minor role in the formation of the embryo".

In The Caring for the Self, Foucault (2014a) also analyzes Artemidorus's key to dreams, for whom penetration is the qualifier of the sexual act, so that lesbian dreams mean negative things, even in business and finance. This explains the reason why dreams, in Artemidorus, are strongly marked by the male character and the importance attributed to virility. In this sense, the sexual act is a power game, between higher and lower, in which penetration is domination for those who do it and submission for those who are subject to it.

We cannot fail to refer to Jean-Jacques Rousseau (1712-1778), who despite countless theoretical contributions in the field of politics and philosophy, bequeathed countless writings that, in the words of Mary Wollstonecraft (2015), made women objects of piety and contempt. The passage in Emilio is particularly interesting, in which the Genevan expressly affirms that the woman's softness can always bring her husband back, 
although the sweet husband, by not preserving his temperament and his particular ways of behaving, can make the very naughty wife (Rousseau 1992).

... the first and most important quality of a woman is sweetness; made to obey a being as imperfect as man, often full of vices and defects, she must learn from an early age to suffer even injustices and to endure her husband's mistakes without complaining (...). The bitterness and obstinacy only increase their ills and the bad procedures of their husbands. (Rousseau 1992, p. 440)

Chronologically, another medical argument that can be remembered, although more current than Galen's, is that of criminologist Cesare Lombroso (1835-1909), for whom women were less criminal than the perfect sex - that of the male. However, she emphasized that the criminal woman had an exacerbated sexuality and intoxicated with perversion, making reference to masturbation and lesbianism (Lombroso and Ferrero 2004).

Sigmund Freud (1856-1939), father of psychoanalysis, also made no major efforts to attribute to women a less oppressive social role than what was being built (and still is today). If, on the one hand, the greatest exponent of psychoanalytic discourse revolutionized when listening to hidden desires, including women, on the other hand, like every good son of his time, he remained conservative when building the female subject. For him, the woman - or "dark continent", as he called her - is an incomplete being who is envious of the phallus, which justifies, in some situations, female hysteria. "The desire with which the girl turns to her father is probably, in origin, the desire for the penis that the mother did not give her and that she hopes to receive from the father" (Freud 2010, p. 284). Therefore, he prescribes that the most sublime moment in a woman's life is when she gives birth to a male child.

Finally, in addition to the above narratives, we cannot fail to mention the religious discourse from Adam and Eve to the present, which reinforces the designation of the male and female role, endorsing the woman and notably the female body as an unauthorized object of desire and joy, but also fear, sin, intrigue and deviation. In this sense, the passage in which God addresses Eve and says: "I will greatly multiply your pain and your conception; with pain you will bear children; and your desire will be for your husband, and he will dominate you" (Bible, Genesis, 3-16), or in Ecclesiastics 2526 , according to which "all malice is light compared to a woman's malice; let the lot of sinners fall on her" (Bible, Ecclesiastics, 25-26). It is known that the Roman Apostolic Catholic Church guided the laws of Roman law in Western laws, which is why the inferiority of women preached by religion was reproduced in them, a situation in which greater considerations will be made in the last point under study.

It is clear that much progress is being made day after day with regard to the female body. However, contemporaneity, especially in Brazil, presents a very particular sadism disguised with a certain charm and which we cannot forget. A kind of discourse embedded in the habitus to which Pierre Bourdieu (2002) refers. Millôr Fernandes (19232012) made the feminist cause the trigger for an easy laugh in his Veja magazine columns by stating, for example, that "the best female movement is still that of the hips" (Fernandes 2002). In this same perspective, Nelson Rodrigues' (1912-1980) wide-open obscenity is widely known, for whom, in a true tone of irony, not every woman likes to be beaten, only normal ones. 
This is the atmosphere in which the female body was framed. It is easy to see that all these manifestations/appropriations of the female body are carried out by men and take into account a binary system, of opposites, in which one pair is always ranked as superior and the other inferior.

There is a mysterious, irrational and dangerous side to femininity. Something true and false, light and shadow, darkness and shining. The woman is a way of saying that the man elaborates on the specificity of his desire (...). (Valdivia 1997, p. 27)

In view of these considerations, the conclusion of the physician and anthropologist Mari Luz Esteban (2004, pp. 115-116) could not be different, in the sense that "the female bodies are speaking, acting, communicating, expressing and materializing different world views, that does not always coincide with what is said about them". In fact, women were included in a discourse whose construction they did not participate in and now, little by little, combining theorizing with social movements, they are trying to make progress in terms of conquering rights and social recognition.

\section{Moi-peau: Decifying the female body (and the female world)}

The French expression moi-peau is a concept of psychology and psychoanalysis developed by Didier Anzieu (1989), who considers the skin as the most vital of the organs, insofar as it is possible to live blind, deaf, mute, without taste, without smell, but without the integrity of most of the skin there is no way to survive. The idea, at this point in the study, is to demonstrate that the psychic, biographical body and the somatic, biological body do not separate. And with that, one does not want to frame and limit the being to its carnal materiality, much the contrary, even because it is known that, sexually speaking, the self often does not identify with its gender of birth, as it is the case of transgender or transsexual, as opposed to cisgender.

It is in the body that life inscribes the events, traits, experiences, experiences and expectations of each individual considered in their uniqueness, which encompasses the most elementary and everyday situations of life, like the vaccines taken, the broken arm because of childhood play, surgical procedures, inadequate posture sustained for years and excessive exposure to the sun.

In fact, from the $20^{\text {th }}$ century onwards, the body assumes an extremely relevant function as a cultural mediator, because it now individualizes and differentiates itself from the others, receiving more and more visibility and importance, including in economic terms. It goes from "I think, therefore I am" to a kind of "I am flesh, therefore I am", because only the body allows the subject to cling to his own existence. It is there that the individual writes his story, formulates his narratives and projects his life expectations. From this perspective, there is no denying that many of our identities are made visible to others through the consumer, beauty and advertising industries. For Corbin, Courtine and Vigarello (2011, p. 13):

The history of the female body is also the story of a domination in which the simple criteria of aesthetics are already revealing: the traditional demand for an always 'modest', virginal and guarded beauty, imposed itself for a long time, before liberations were affirmed decisive repercussions in shapes and profiles, more accepted movements, more expansive smiles, more naked bodies. The history of the body, in other words, could not escape the history of gender models and identities. 
This position is in line with the ideas of the social historian Carol Dyhouse (2011), for whom glamor, in many contexts, engendered a real rejection of the norms of class and gender or the expectations of conventional femininity. For her, therefore, glamor and all the elements that orbit around it represented more rebellion, daring and subversion than female submission. In this same sense, for Gilberto Freyre (1987, p. 33):

It can be said of the woman who tends to be, as for fashions for her dresses, her shoes, her hairstyles, somewhat maria-go-with-the-others. Therefore, corresponding to what the fashion has to uniform. But the initiative of women to react against this absolute uniformity, according to personal characteristics that do not adjust to the impositions of a fashion of this or that, is of feminine wit. In this regard, it is necessary to recognize, in the Brazilian brunette, the right to repudiate North European fashions aimed at blond and white women.

Likewise, Lipovetsky (1999, pp. 117-118), when making his considerations about what he calls the fair sex, assures that although the female body has been studied, investigated, decomposed and recomposed, everything to make fame possible of those who interpret it - the painter, the poet - there is no way to strictly assimilate the hymns to the fair sex as a form of relegation of the feminine.

... It does not fit to assimilate purely and simply, hymns to beautiful sex to an instrument of alienation of women; by specifying an unprecedented recognition and assessment of female prerogatives, they allowed both to promote a social and symbolic promotion of women (...). Hence the historical irruption of beautiful sex should be interpreted less as a new figure of the relegation of the feminine than as one of the first milestones of modern dynamics that engendered the recognition of the human and social dignity of women.

The problem lies in the fact that a large part of feminist and activist theories consider the female appearance in a restricted way, as if the woman were an absolutely passive being and submitted to the laws of the market and the beauty, fashion and aesthetic industry. Esteban (2004) understands that this path does not favor female empowerment, as it is necessary to make women not victims, but agents of their own history. Thus interpreted, the female body is again fragmented, making it an object of pleasure within a sophisticated and elegant game of cult to female beauty, fragility and vulnerability (Lipovetsky 1999). Making this statement does not mean saying that gender norms do not have harmful consequences for women. On the contrary, it implies observing the concrete experience of each one of them, without homogenizing them or converting them into absolutely inert beings, a circumstance that goes step by step with victimization. It is essential, therefore, to recognize that women have the capacity to generate alternative proposals to at least compensate for the disadvantaged situation to which they are subjected.

It is evident that the fact that aged faces do not appear frequently in the media, for example, communicates a message that, although subtle, implies the body awareness of women and girls. It happens that, it is necessary to work with the idea that men and especially women negotiate their place in society from the administration of corporal materiality, image and aesthetics.

Feminist discourses, therefore, have had to deal with the overriding need to adapt to new changes and regulations in women's bodies, which imply new definitions of feminine, woman and femininity. Feminism at the end of the $20^{\text {th }}$ century raised the 
banner of protecting reproductive rights (or non-reproduction), which implied a sexual and erotic look at the body. The $21^{\text {st }}$ century, on the other hand, has made the body an economic, consumption, exhibition and visibility object. Therefore, it can be said that the female body of contemporaneity is, to a large extent, the body of aesthetics, of the image, of the visible, of the seen.

Regarding specifically to the issue of gender, we agree with Esteban's (2004) position that a considerable part of the problem of inequality between men and women lies in the absolutely sectarian definition of feminine and masculine that attributes to each biological body characteristics aesthetic and even sketches that must be performed by the male or female. In fact, the approximation between law and sexuality has always evolved in the sense of obeying a patriarchal normative logic. With that, heterosexual binary was established as being normal, whereas any other possible manifestation of sexuality received the label of abnormal referred to by Foucault (2014b). In other words, the naturalized discourse narrates an intelligible being only insofar as it acquires a gender that, in turn, must also be intelligible (Butler 2016), embodied in that coherence and continuity between sex, gender, sexual practice and desire.

Even before birth, the child (the human in becoming) is enrolled in one or another sexual class. There is no human being. That guy who wasn't even born is (will be) a boy or a girl. This prior designation is responsible for determining a series of consequences for the self, because in the binary order of the sexes (male or female) there is a very clear expectation about the behaviors expected for each nomenclature, almost as if this assignment would colonize and conform the individual. This derives, to a large extent, from the prototypes of masculinity and femininity. Women are more easily associated with the dimension of care, affection, passion and supposedly have a monogamous tendency. Men, on the other hand, are linked to rationality, protagonism at work, virility and strength. That is why, in addition to being a binary logic - since it is always limited to two terms, since assuming one excludes the other (male or female, heterosexual or homosexual) - there is also the attributive circumstance, in the sense that each of these poles is assigned certain characteristics, usually complementary and opposite, which fix the "one" or "other" of the pair in a hierarchical position. This hierarchy, however, is not limited to the field of sexuality (although it constantly flows into it), encompassing other categories such as race, social class and ethnicity. In this sense, for Herrera Flores (2005), the expression "patriarchalism" contemplates better than "patriarchy" the fact that there is a set of relationships that articulate a corresponding set of oppressions. That is to say, patriarchal relationships cannot be adequately visualized or understood if they are seen apart from other relationships. "Class structures, racism, gender and sexuality cannot be treated as independent variables, because the oppression of each one is inscribed in others" (Herrera Flores 2005, p. 29).

In this perspective, skin color is also a relevant identity trait. It is quite illustrative that the brunette and especially the black have been marked by an erotic character in our culture. In Portuguese lands, for example, there was a special attraction for blond hair. However, the brunette and the black were preferred for erotic, physical, carnal love. The literature of the eighteenth and nineteenth centuries clearly delineates this masculine appreciation for the brunette and the dark skin, the black hair in great quantity and the 
eyes of jaboticaba (Brazilian grape). The blonde, in turn, was related to the upper classes (Del Priore 2000).

It is curious to think that, even today, the vast majority of women victims of sexual violence is formed by black and brown women (Novaes 2016), as if their bodies were available and that was their natural destination.

This circumstance highlights the complex racial tensions that exist especially in the Latin American scenario between blond, dark and black bodies. With regard specifically to Brazil, a recent study by the Security Observatories Network (2020), entitled The color of violence: An analysis of homicides and sexual violence in the last decade, showed that in 2017, black women were the victims of $73 \%$ of sexual violence cases in Brazil. Young black men, on the other hand, form the population most affected by violent deaths in Brazil. In Brazil, black men had a rate of 89 per 100,000 inhabitants in terms of violent deaths. Among white men, the indicator was 28 per hundred thousand. Therefore, vulnerabilities are seen that cross over in the same body, in the same biographical stage.

In addition to sexual exploitation and violence and now immersed in the field of supposedly consensual relations, Moroccan sociologist Eva Illouz asserts that feminism has not yet realized that the struggle for sexual freedom for women can be, before and in fact, the consecration of a male model of sexuality. This perception can also be found between the lines of Gregori's (2016, p. 203) work, for whom it is really difficult to predict the impact of new eroticisms on gender conventions and sexualities, because, on the one hand, these transformations

allowed the expansion of tolerance and the scope of sexual experiments, as is clear from the diversity of uses of erotic goods. On the other hand, there is a risk of holding women responsible for maintaining the sexual happiness of romantic relationships, reinforcing an erotic etiquette composed of still strongly heteronormative conventions.

This is because the notion that happy, emancipated and independent women who live their sexuality intensely has been sustaining itself in contemporary societies. Added to this is Illouz's (2016) understanding that there are still striking distinctions between male sexuality - more focused on casual sex - and female sexuality - more easily assimilated to sexual exclusivity and emotional involvement (albeit minimal). If women allow themselves to live their sexualities more freely - and this obviously has a positive side on the other hand, it is necessary to recognize that gender stereotypes can bring problematic consequences with regard to women who intend to marry or share their lives with someone, notably in heterosexual relationships, as men (unfortunately) continue to classify women in a hierarchical order that conceives them as ideal for marriage or not.

All of these analyzes demonstrate in a very emblematic way that the sphere of sexuality also has its own policy of inequalities and modes of oppression, even when it involves situations that, in theory, are allowed, which is why female empowerment cannot do without carnal materiality. Indeed, it is agreed with Gayle Rubin (1992) that "sexual legislation" is a rigid and efficient mechanism for regulating social behavior, so that the State interferes in people's sexual behavior in such a way that it would not be tolerated in other fields of life. 
In addition to the consequences in the universe of desire, sexuality and violence, much of the differences and particularities that were designed for each gender are reflected also in the ways of dressing. And here it is worth remembering Lipovetsky (2004), for whom fashion is not only a product of the consumer society, but a social institution. In this sense, it is important to bring to the debate a May 2016 article published in the Style magazine, whose theme revolves around gender neutrality that now appears in the ways of dressing and consuming. The androgynous tendency is, in fact, contemporary, but it began to take shape in the First World War (1914-1918), considering that women had to take on the work that men could no longer do because they were in the camps. battle.

In 1966, Yves Saint Laurent created the unisex Le Smoking. Jean Paul Gaultier, in Paris, Alexandre Herchcovitch, in São Paulo and the Spanish Zara are betting more and more on underground collections whose pieces can be used simply by people, regardless of gender. These "recent examples show that non-gender can have the potential to transform the way we consume" (Garcia 2016, p. 36).

Still in this perspective of the fashion world, it is also symptomatic that the American Pantone Inc., known worldwide for having developed the first color system in 1963, selected as the color of the year 2016, for the first time in history, a mixture of two tones: Rose Quartz, a warm pink as a hug, and Serenity, a cooler and quieter bluish tone, according to the company's own descriptions. The choice was made in clear reference to the movements of gender equality and fluidity in terms of fashion.

Historian Mary Del Priore (2000) is relatively skeptical about standards of beauty and aesthetics. She says that women of the 21st century have switched from submission to parents, partners, bosses and patriarchy in general, for the domination of the media and advertising and their impositions. Not that this did not happen in other times, but it is necessary to agree that in times of globalization (economic, cultural, political, social, technological and aesthetic, inclusive) the figure of the ideal body remains standardized. In fact, "there is no prison more violent than the one that does not allow us to change" (Del Priore 2000, p. 99).

In this sense, the female body and its facets can collaborate for the empowerment of women and for the conquest of rights and recognition. The body must be understood not as the prison of being, but as its liberation, not as castration, but as possibilities within (and outside) the freedoms that life offers. In this sense, the hypervisibility of the body is not interpreted negatively, but as a catalyst for female empowerment.

In reality, the problem is not in the visualization of the female body - even because it has been visualized astronomically, day after day, in advertising, in the porn industry, in art - but in the way it happens. We must now see the unseen. In short, one cannot reduce being to the body, to the carcass, but neither can one reduce the body to being, to the mind. It is necessary to analyze both dimensions together, making the body subject and agent of social transformation, because we are condemned to live in our envelope. Psychoanalysis endorses this argument by stating that it is through the other that bodily unity is prefigured and anticipated. For this reason, the Brazilian psychiatrist and psychotherapist Joel Birman (1999, p. 35) affirms that the construction of the unified self and body "are the two faces of the same reality, because for the subject, the experience of having and being me implies for him inhabit a unified body. The condition of unified 
refers to the notion of being one, one, me, matter, body that is inscribed in space and in the world".

In this same sense, for Foucault (2006, p. 233):

My body, in fact, is always elsewhere. It is tied to all the elsewhere of the world. And to tell the truth, it is elsewhere than in the world, because it is around it that things are arranged. It is in relation to it - and in relation to it as if in relation to a sovereign - that there is a below, an above, a right, a left, a forward and a backward, a near and a far. The body is the zero point of the world.

In line with the argument advocated by Esteban (2004), it is believed that female empowerment and, therefore, women's emancipation, will occur through their bodies, or will not occur. This is because it is the organic body itself, of flesh, blood and humors, the symbolic place on which approximations, definitions and standards were built that relegate women to a secondary position in society, so that "the study of gender cannot escape the body, its materiality, social and bodily interaction" (Esteban, 2004, p. 243).

In other words, the body is not limited to a space of society and culture in which biographies are inscribed. It is an object, but, above all, the being itself and, therefore, subject.

... Perhaps it can already be said that the subject does not have a body, but that the subject is a body, because we are talking about something that is one in subjectivity and in corporeality, a singular articulation. (Lazzarini and Viana 2006, p. 243)

Finally, it must be said that empowering is not synonymous with beautifying, glamorizing, performing, stereotyping, but allowing women to accept their bodies and recognize the plurality of shapes and curves that draw the female silhouette and their experiences, because these two dimensions - body and mind - are not separated, because ultimately, all social contradictions and disputes (social class and age, for example) imply the materiality of the body.

For this reason, Esteban (2014) concludes that we, women, are condemned to enhance our body awareness - or our "self-care", to evoke a Foucauldian (2014) expression. The woman is called upon to be, more than ever, extremely narcissistic (in terms of selfknowledge) in relation to her body. This implies making positive bodily experiences visible, insofar as they can generate a very direct and beneficial influence regarding the subjectivity of women. In general terms, Esteban proposes that it is possible to transform the subject's body itinerary, resisting and challenging social structures. However, in order for this to happen,

both feminism and anthropology should definitely give up the dephosphorization that they are suffering and take into account once and for all the carnality of human experience. (Esteban 2004, p. 245)

Regarding to positive bodily experiences, it is important to note Mariella Pandolfi based on the study of female reports on symptoms and illnesses, in the sense that

cette manière et plus complexe de reconter em se racontant montre que dans la vie sociale, les femmes ont tendance to be constructed with an identité partielle from the desfaites, des evénements négatifs (...). (Pandolfi 1993, p. 66)

Michele Perrot (2003, p. 26) advocates the "need for women to appropriate them, to fight for the knowledge and autonomy of their bodies, a great banner of contemporary 
feminism". Anyway, it is believed that only empowerment and emancipation related to body image will gradually enable recognition and progress in terms of gender equality.

Concluding this point of the work, it is possible to quote the work Le Viol, by the Belgian surrealist René Magritte. The painting is truly disturbing and makes the observer wonder about what is actually seen: would it be a body in a head or a head in a body? Magritte sees a body that, in theory, would be out of sight of the frame. With this, it is intended to reiterate, in another way, what has been said so far, in the sense that if there is a being, there is also carnal materiality. Both dimensions mix, giving form and substance to each particular individual.

\section{5. "Your body is a battleground": The law approves the female body}

The sentence chosen to name this text, and which now stands as the title of the fifth section of the research, is inspired by the photographic silkscreen on vinyl by the American graphic artist Barbara Kruger. The work was produced in support of reproductive freedom and, therefore, in clear allusion to the fact that the body, specially the female, is a symbolic battlefield in which the struggles that inscribe on the subject whose biological body is female a pre-determined narrative are fought. It is art, but it is also protest. In theoretical terms, for Carolina González Laurino (2008, pp. 18-19):

The body appears as the material expression that translates a set of ideas and symbols and shows, on the aesthetic level, the design of a socially modeled subject. The vital trajectory appears, then, takes shape in a way that communicates socially in spite of the subject.

It is a fact that the body has been the stage of public struggles for women in a way never before seen or perhaps imagined. For this reason, Lipovetsky (1999) will state that the contemporary woman or the "third woman" is a real unknown. The first woman was demonized and depreciated. The second was placed on a pedestal. Despite the differences in treatment, in all cases the woman was being thought, elaborated and built in relation to - and by - the man. Her way of being and being in the world was ordered based on pre-established situations: getting married, having children, managing household chores and taking care of her husband. For them, the private. For them, whatever they wanted.

Now, for the first time in history, women's destiny enters an era of total unpredictability that, to a large extent, derives from the enormous range of options that are now available to women, albeit to a lesser extent than occurs with men. "Everything, in the female existence, is now the object of election, interrogation and arbitration" (Lipovetsky 1999, p. 219). When this possibility of self-determination flows into the woman's body, in her curves, in her mobility and in her inconsistencies, the right is called upon to manifest itself under the logic of licit-illicit, regulating and, consequently, pruning freedoms and possibilities of the meat. Indeed, when women are no longer complicit in the role of the phallus, the traumatic elements of machismo become even more evident (Giddens 1993).

In the meantime, the uniform application of legal norms is related to the respect for formal equality typical of Modernity, but also to the requirement of legal security in the liberal model. It happens that, in contemporary times, there is no way to disregard, in the name of order, certainty and formal equality, the new social demands headed by difference, pluralism and diversity. 
Globalization has made evident (or at least made it possible) the appearance of the immense diversity that until then had been covered by the fictitious mantle of equality. In this sense, Warat (2000) will affirm that equality is castration, that is, pruning, a true annihilation of the desires that pulsate in each human being in relation to their diversity and their desire to, perhaps, be different things. Therefore, it is possible to conclude that equality emerges as an institute that narrates the world with the concealment of all beauty and intensity of chaos, disorder, uncertainty, diversity and pluralism. In this tendency of distrust in the face of great narratives, the issue of the body appears in a very emblematic way.

Therefore, it is not by chance that Western modern societies have formed an experience from which the subjects signify themselves in terms of sexuality within a heteronormative control system, whose logic is binary and clearly hierarchical (Santos and Lucas 2015). For this reason, Foucault $(1979$, p. 262) states that "with your sex, you will not simply manufacture pleasure, you will manufacture truth", because just like the madman's word denounces his madness, my sex will talk about my body, about my essence, about my truth, in short, about myself.

So, when bodies (and, needless to say, being) signify, dress, perform, love, desire, in short, they exist in ways different from those pre-established in relation to the experience of bodily materiality, contemporary culture creates the devices needed to correct and transform this abnormal body, normalizing, regulating, castrating. Furthermore, although the legal system tries to include it, it does so by excluding. In other words, recognizing a body's conduct implies excluding the others, which will postulate equivalent recognition, and this seems to be the schizophrenic logic of a society that has fragmented and capillarized so much that it postulated a kind of certification in absolutely all of its activities. facets.

It so happens that the corporal experience has become so diversified and assorted that the law and its institutes no longer take account (if they ever did) of the task of disciplining all behaviors related to bodies. In this sense, Richard Miskolci (2006) considers that contemporary society has been constantly proposing technical means to resolve issues that would only be effectively resolved by profound social changes. In fact, embodying identities through the law entails, albeit not on purpose, a reduction of all human complexity to physical and visible forms.

In fact, the treatment that the law gives to the body is arbitrary because it will usually imply an abysmal separation between men and women. Although there is a certain resistance of the bodies to disciplining, it cannot be denied that it is always a limitation. What we want to demonstrate is that the law should not be an institute used to regulate absolutely all experiences and body representations. It is evident that there are legal provisions regarding carnal materiality that are of fundamental importance - such as the child's inaccessible body, for example - but taking this prerogative to the extreme means interfering in the private lives of individuals in a totally arbitrary way.

When article 13 of the Brazilian Civil Code of 2002 provides that "except for medical reasons, the act of disposing of one's own body is forbidden when it comes to permanent reduction of physical integrity, or to contravene good customs", what does it say? What would be good customs? In this perspective, the body as liberation and power of being is denied. In fact, it is interesting to mention that part of the most critical doctrine and 
even the jurisprudence has seen the expression "good customs", so present in the Brazilian legal system, with some suspicion.

Still in the Brazilian Civil Code, for example, art. 187 provides that "the holder of a right also commits an unlawful act which, when exercising it, manifestly exceeds the limits imposed by its economic or social purpose, good faith or good customs". In this sense, the doctrinal statement approved at the 5th Conference on Civil Law establishes that "the general clause of art. 187 of the Civil Code is constitutionally based on the principles of solidarity, due to the legal process and protection of trust, and applies to all branches of law". In other words, the perception of the illegal act based on the notion of good customs is projected not only in civil law, but in absolutely all branches of law. The statement of number 413, in turn, approved at the same Conference, establishes that "the good customs provided for in art. 187 of the CC have a subjective nature, aimed at controlling social morality of a certain time, and objective, to allow the investigation of the violation of legal affairs in matters not covered by the social function and objective good faith". It is not surprising, therefore, some of the doctrinal and jurisprudential criticisms made to the infamous "good customs", which are, in the last case, instruments of surveillance, of morality control.

The big problem is that we live in somewhat strange times. How can we define morality in an environment in which anti-democratic and anti-human rights threats are incessant, embodied, for example, in the discourse "human rights for human rights"?

Recently, Brazil was the scene of the most extreme perplexity: in the state of Espírito Santo, a 10-year-old girl was pregnant after being sexually abused by her uncle. The pregnancy was revealed when the girl went to the hospital, complaining of severe abdominal pain. Investigations found that the girl had been raped by her uncle since the age of 6 and did not report because she was constantly threatened by him. The Brazilian Penal Code of 1940 authorizes, in its art. 128, item II, termination of pregnancy if it results from rape and there is consent from the pregnant woman or, in the case of incapacitated, from the legal representative. But the situation, apparently possible to be solved with the literalness of the norm, took on at least complex outlines because groups, especially religious, tried to pressure the girl's grandmother so that the abortion was not authorized. The child had to leave Espírito Santo, having been transferred to the Integrated Health Center Amauri de Medeiros, in Recife, a referral unit for abortion cases provided for by law and authorized by the courts. The girl, who was about 22 weeks pregnant, finally managed to perform the procedure (Jordão 2020).

The fact narrated above seemed the perfect opportunity to discuss measures that could reduce the bureaucracy at least in cases such as those listed in art. 128 of the Brazilian Penal Code (humanitarian or sentimental abortion). However, a recent Ordinance of the Ministry of Health that, it seems, was elaborated precisely because of the social repercussion of the fact involving the pregnant girl, ${ }^{1}$ includes among the procedures it is suggested that the pregnant woman see the fetus by ultrasound, as well as submitted

\footnotetext{
${ }^{1}$ The social repercussion became even bigger when the extremist Sara Geromini discloses, in clear affront to legislation that is not only national, but also international, involving children and adolescents, the child's name and address (Oliveira 2020). The former employee of the Ministry of Women, Family and Human Rights stated, nonetheless, that she would sue the doctor who performed the authorized abortion on the girl (Teodoro 2020).
} 
to an extensive questionnaire on rape, mechanisms that are, without exaggeration, mechanisms that refer to torture practices. As if this were not enough, the Ordinance obliges doctors to notify the police about requests for legal abortion in cases of rape. The Federal Public Defender's Office has already filed a public civil action against the Ordinance, and until the end of this research, there was no jurisdictional position in this regard. The fact is that the Ordinance shows, once again, an attempt to colonize the bodies, notably the female and pregnant.

In Argentina, also recently, a 10-year-old girl was raped by her mother's partner. The child continued with the pregnancy and was forced to participate in a baby shower, organized by members of a religious institution against abortion (Carbajal 2020).

These are just two brutal examples of the control of female bodies, not only in charge of law, but also of public opinion and the supposed morality imbricated in "good customs". Therefore, with regard specifically to the female body, it appears that the law appropriates it in a very specific way, regulating behaviors related to reproduction, contraception, abortion, prostitution and sterilization (especially in young women), that is, sexuality in a different way. general. This stems from the fact that the female body has always been either demonized or placed on a pedestal, so that either the woman was associated with marriage and motherhood and is therefore pure, or Satan, and therefore impure. And why is it difficult for law (if not impossible) to make efficient regulation of bodies? Perhaps, due to the fact that much of the law is embedded in fallacious concepts such as those of morality and "good customs".

Despite the fact that we have witnessed very significant advances in terms of the achievement of women's rights, setbacks are denounced all the time. Therefore, it is not surprising - although it should be - that the Federal Senate, through its page on the social network Facebook, asked whether "Brazilian women should lose the legal right to terminate pregnancy resulting from rape" (Fernandes 2016). Situations like this only corroborate the fact that human rights are truly fragile institutes and permeated by power relations, which is why the struggle in their favor must be a constant exercise, especially of vulnerable groups, such as women.

Foucault (1979) was right when he stated that learning to behave, to move, to be precise and rhythmic, are manufactured and produced gestures and feelings. This whole training is the result of the application of positive techniques - and not only of repression - as they act on desire and knowledge, so that the body becomes useful and efficient, but at the same time docile and submissive. Take, for example, law № 9.263 of 1996, which provides for family planning. It establishes the restricted cases in which voluntary sterilization is allowed, being that the man or the woman must be over 25 years of age, full civil capacity or at least two living children. In the final part of item I, it is expressly stated that it is possible to subject the interested person to multidisciplinary counseling, "aiming to discourage early sterilization". That is, if the State adopted a policy in the opposite direction, that is, of reducing birth rates, it is evident that such a law would not even exist in our order. In fact, the system of body control is perverse and at the same time brilliant, because we simply do not realize the power that is exercised over us.

The law says a lot when a situation in the planning is positive, but it says even more when it says nothing. That is, when the consequences are omitted, they are as severe as those arising from the express and exact recognition of a given circumstance. In this 
respect, it is emblematic that the bisexual does not find legal support to address his sexuality, because from the point of view of the legal system it simply does not exist. For this reason, Judith Butler (2015) will state that it is necessary to make bodies visible, as those that materialize obtain social legitimacy. On the other hand, the body despised by the norm is relegated to invisibility, to indifference.

These are, in fact, just a few examples, but they already allow us to conclude that the corporal experience has become so diversified and assorted that the law, as a legal norm, simply does not handle the task of regulating all the related conducts, because above all the body it is not something you have, but something you are. The great nonsense may be related to the fact that the more the law seeks to protect the bodily integrity of the human being through the norm, the more the individual receives autonomy from the will to dispose of it. Ultimately, these paths do not cross, that is, they are irreconcilable, and it is in this horizon that bodies are made, developed and exist, alien to disciplinarization, which is increasingly oppressive, but also less effective.

\section{Final considerations}

The present study aimed to demonstrate, at first, that the female body was always narrated by men from a binary system that ranked men as superior and women as inferior. Plato, Aristotle, Hippocrates, Galen, Freud, Rousseau: all used, each in their own way, the discourse that the inferiority of women is natural, supporting legal and constitutional practices of regulation between the sexes, justifying the inferiority and female submission.

It cannot be denied that except for the rare matriarchal communities in the world today, the majority of peoples - including the western one - have organized and are still developing today so that women and girls are, to a greater or lesser extent, constantly exposed to violence arising from gender inequality. However, contemporary society has experienced a real subversion of the role that has been attributed to women throughout history, so that currently female bodies assume a way of being and being in the world that does not always - or rarely - coincide with what said about them.

For this reason, it is imperative to recognize that the history of women - told and actually lived by them - is, contrary to popular belief, very recent, and to some extent it coincides with the visibility of the female body. So much so that contemporary feminist movements take a stubborn defense of the idea of "my body, my rules". Despite some significant advances, contemporary societies have developed such sophisticated and subtle ways to exercise control over bodies that we do not even perceive such a circumstance without a careful and critical exercise of our surroundings.

In addition, the study sought to demonstrate that even in Western liberal societies, like Brazil's, human rights must be understood as a process of constant and uninterrupted struggle, as the more conservative sectors of the National Congress stimulate and promote setbacks that affect considerably the rights of the most vulnerable groups, including women. In this sense, the lines of Brazilian legislation show the perverse and refined apparatus of control over female bodies, especially with regard to sexuality, because this aspect of life is, par excellence, a way of expression, but also of meaning, and not there is no easier way to exercise power than by regulating the subject's intimacy. 
One concludes, therefore, that more than a passive spectator, the organic body can be a path to liberation, being necessary, therefore, to stimulate self-knowledge and self-love in relation to the body itself. The challenge, now, is to build a new world view from narratives that conceive the woman's biological body no longer as an object, but as a subject, as the protagonist and agent of her own history. Galeano's poem presages what may be happening to our bodies: we are subverting the idea of the body as guilt, machine and business, to experience it as a party.

\section{References}

Anzieu, D., 1989. O eu-pele. São Paulo: Casa do Psicólogo.

Aristotle, 2010. Partes dos animais. Trans.: M.F.S. Silva. Lisbon: Imprensa Nacional, Casa da Moeda.

Bedin, G.A., 1997. Os direitos do homem e o neoliberalismo. Ijuí: Unijuí.

Birman, J., 1999. Cartografias do feminino. São Paulo: Editora 34.

Bourdieu, P., 2002. A dominação masculina. Trans.: M.H. Kühner. $2^{\text {nd }}$ ed. Rio de Janeiro: Bertrand Brasil.

Bozon, M., 2004. Sociologia da sexualidade. Trans.: L. Menezes. Rio de Janeiro: FGV.

Butler, J., 2015. Cuerpos que importan: Sobre los límites materiales y discursivos del "sexo". $2^{\text {nd }}$ ed. Buenos Aires: Paidós.

Butler, J., 2016. Problemas de gênero: Feminismo e subversão da identidade. Trans.: R. Aguiar. $10^{\text {th }}$ ed. Rio de Janeiro: Civilização Brasileira.

Carbajal, M., 2020. Niña abusada en Corrientes: le hicieron la cesárea. Página 12 [online], 10 September. Available from: https://www.pagina12.com.ar/290900nina-abusada-en-corrientes-le-hicieron-la-cesarea [Accessed 13 September 2020].

Colling, A.M., 2014. Tempos diferentes, discursos iguais: A construção do corpo feminino na história. Dourados: UFGD.

Corbin, A., Courtine, J.J., and Vigarello, G., eds., 2011. História do corpo. As mutações do olhar: o século XX. Trans. and rev.: E.F. Alves. $4^{\text {th }}$ ed. Petrópolis: Vozes.

Del Priore, M., 2000. Corpo a corpo com a mulher: Pequena história das transformações do corpo feminino no Brasil. São Paulo: SENAC.

Dyhouse, C., 2011. Glamour: Mujeres, historia y feminismo. Trans.: J. Emery. Buenos Aires: Claridad.

Esteban, M.L., 2004. Antropología del cuerpo: Género, itinerarios corporales, identidad y cambio. Barcelona: Bellaterra.

Featherstone, M., 2009. Trasformazioni: Corpo, imagine ed affect nella cultura dei consumi. In: G. Guizzardi, ed., Identità incorporate: Segni, immagini, differenze. Bologna: Il Mulino.

Fernandes, M., 2002. Millôr definitivo: A Bíblia do caos. Porto Alegre: L\&PM. 
Fernandes, M., 2016. Senado faz enquete polêmica sobre aborto em caso de estupro. Exame [online], 30 June. Available from: https://exame.com/brasil/senado-ignoralei-e-pergunta-se-o-aborto-dever-ser-autorizad/ [Accessed 13 September 2020].

Foucault, M., 1979. Microfísica do poder. Trans.: R. Machado. Rio de Janeiro: Graal.

Foucault, M., 2006. Utopian body. In: C.A. Jones, ed., Sensorium: Embodied Experience, Technology and Contemporary Art. Cambridge, M/A/London: The MIT Press and MIT List Visual Arts Centre, pp. 229-234.

Foucault, M., 2014a. História da sexualidade: o cuidado de si. Trans.: M.T.C. Albuquerque. São Paulo: Paz e Terra.

Foucault, M., 2014b. Os anormais: Curso no Collège de France. São Paulo: WMF Martins Fontes.

Freud, S., 2010. O mal-estar na civilização, novas conferências introdutórias à psicanálise e outros textos (1930-1936). Trans.: P.C. de Souza. São Paulo: Companhia das Letras.

Freyre, G., 1987. Modos de homem, modas de mulher. Rio de Janeiro: Record.

Galimberti, U., 2010. Il corpo. 20 $0^{\text {th }}$ ed. Milan: Feltrinelli.

Garcia, C., 2016. Será o fim do gênero na moda? Style: Estilo de Vida, nº 164, maio, pp. 34-37.

Giddens, A., 1993. A transformação da intimidade: Sexualidade, amor e erotismo nas sociedades modernas. Trans.: M. Lopes. São Paulo: UNESP.

González Laurino, C., 2008. Identidad y percepción social del cuerpo. In: T. Porzecanski, ed., El cuerpo y sus espejos: Estudios antropológico-culturales. Montevideo: Planeta.

Gregori, M.F., 2016. Prazeres perigosos: Erotismo, gênero e limites da sexualidade. São Paulo: Companhia das Letras.

Herrera Flores, J., 2005. De habitaciones propias y otros espacios negados: Una teoría crítica de las opresiones patriarcales. Bilbao: Universidad de Deusto.

Hippocrates, 2007. Aforismos. São Paulo: Martin Claret.

Illouz, E., 2016. ¿Por qué duele el amor? Una explicación sociológica. Buenos Aires: Katz.

Jordão, P., 2020. Menina de 10 anos volta para o Espírito Santo após ter gestação interrompida. Estadão [online], 19 August. Available from: https://brasil.estadao.com.br/noticias/geral,menina-de-10-anos-volta-para-oespirito-santo-apos-ter-gestacao-interrompida,70003404940 [Accessed 13 September 2020].

Lazzarini, E.R., and Viana, T.D.C., 2006. O corpo em psicanálise. Psicologia: Teoria e Pesquisa [online], 22(2), pp. 241-249. Available from: https://doi.org/10.1590/S0102-37722006000200014 [Accessed 14 July 2016].

Lipovetsky, G. (with S. Charles), 2004. Os tempos hipermodernos. Trans.: M. Vilela. São Paulo: Barcarolla. 
Lipovetsky, G., 1999. La tercera mujer: Permanencia y revolución de lo femenino. Trans.: R. Alapont. Barcelona: Anagrama.

Lombroso, C., and Ferrero, G., 2004. Criminal Woman, the Prostitute, and the Normal Woman. Trans.: N.H. Rafter and M. Gibson. Durham: Duke University Press.

Miskolci, R., 2006. Corpos elétricos: do assujeitamento a estética da existência. Estudos Feministas [online], 14(3), p. 272. Available from: https://doi.org/10.1590/S0104026X2006000300006 [Accessed 14 July 2016].

Novaes, M., 2016. “É preciso discutir por que a mulher negra é a maior vítima de estupro no Brasil" [Interview with Djamila Rivero]. El País [online], 23 July. Available from: http://brasil.elpais.com/brasil/2016/07/14/politica/1468512046 029192.html [Accessed 28 July 2016].

Oliveira, J., 2020. Justiça manda redes sociais apagarem publicações com dados que expuseram menina vítima de estupro. El País [online], 17 August. Available from: https://brasil.elpais.com/brasil/2020-08-17/justica-manda-redes-sociais-apagarempublicacoes-com-dados-que-expuseram-menina-vitima-de-estupro.html [Accessed 13 September 2020].

Pandolfi, M., 1993. Le self, le corps, la "crise de la présence". Anthropologie et Sociétés [online], 17(1-2), pp. 57-77. Available from: https://doi.org/10.7202/015251ar [Accessed 14 July 2016].

Perrot, M., 2003. Os silêncios do corpo da mulher. In: M.I.S. Matos and R. Soihet, eds., O corpo feminino em debate. São Paulo: UNESP, pp. 13-27.

Plato, 1996. Diálogos: Fédon ou da alma. São Paulo: Nova Cultural.

Plato, 1997. A república. Trans.: E. Corvisieri. São Paulo: Nova Cultural.

Quijano, A. 2005. Colonialidade do poder, eurocentrismo e América Latina. In: E. Lander, ed., A colonialidade do saber: Eurocentrismo e ciências sociais. Perspectivas latino-americanas. Buenos Aires: CLACSO, pp. 118-142.

Resta, E., 1997. Le stelle e le masserizie: Paradigmi dell'osservatore. Rome/Bari: Laterza.

Resta, E., 2011. L'identità nel corpo. In: S. Rodotà and P. Zatti, eds., Il governo del corpo. Milan: Giuffré.

Rousseau, J.J., 1992. Emílio ou da educação. Trans.: S. Milliet. Rio de Janeiro: Bertrand Brasil.

Rubin, G., 1992. Thinking sex. In: H. Abelove, M.A. Barale and D.M. Halperin, eds., The Lesbian and Gay Studies Reader. New York/London: Routledge.

Santos, A.L.C., and Lucas, D.C., 2015. A (in)diferença no direito. Porto Alegre: Livraria do Advogado.

Security Observatories Network, 2020. Violência e racismo na Bahia. Rede de Observatórios da Segurança [online], 12 March. Available from: http://observatorioseguranca.com.br/violencia-e-racismo-na-bahia/ [Accessed 7 September 2020]. 
Teodoro, P., 2020. Sara Winter diz que vai processar médico que fez aborto autorizado em menina de 10 anos. Fórum [online], 17 August. Available from:

https://revistaforum.com.br/brasil/sara-winter-diz-que-vai-processar-medico-quefez-aborto-autorizado-em-menina-de-10-anos/ [Accessed 13 September 2020].

Valdivia, O.B., 1997. Psicanálise e feminilidade: algumas considerações. Psicologia: Ciência e Profissão [online], 17(3), pp. 20-27. Available from:

https://doi.org/10.1590/S1414-98931997000300004 [Accessed 15 July 2016].

Warat, L.A., 2000. A ciência jurídica e seus dois maridos. $2^{\text {nd }}$ ed. Santa Cruz: EDUNISC.

Wollstonecraft, M., 2015. Reivindicação dos direitos das mulheres. Trans. and notes: A.R. Carmo. São Paulo: EDIPRO.

Legal sources

Decreto-Lei no 2.848, de 7 de dezembro de 1940, de 10 de janeiro de 2002. Código Penal [online]. Available from: http://www.planalto.gov.br/ccivil 03/decretolei/del2848compilado.htm [Accessed 26 June 2016].

Lei no 10.406, de 10 de janeiro de 2002. Código Civil [online]. Available from: http://www.planalto.gov.br/ccivil 03/leis/2002/110406.htm [Accessed 26 June 2016].

Lei $n^{0}$ 9.263, de 12 de janeiro de 1996. Regula o $§ 7^{\circ}$ do art. 226 da Constituição Federal, que trata do planejamento familiar, estabelece penalidades e dá outras providências [online]. Available from:

http://www.planalto.gov.br/ccivil 03/leis/L9263.htm [Accessed 3 July 2016].

Portaria n⿳⺈ 2.282, de 27 de agosto de 2020. Dispõe sobre o Procedimento de Justificação e Autorização da Interrupção da Gravidez nos casos previstos em lei, no âmbito do Sistema Único de Saúde-SUS [online]. Available from:

https://www.in.gov.br/en/web/dou/-/portaria-n-2.282-de-27-de-agosto-de-2020274644814 [Accessed 13 September 2020]. 